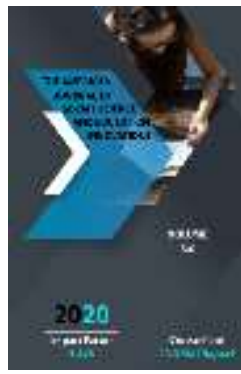

\title{
Nationalism And Universality In Ethnoculture
}

\author{
Ozoda Djalolitdinovna Nishanova \\ Doctor of Science of Philosophy, Professor, National University of Uzbekistan
}

Journal Website:

http://usajournalshub.c om/index,php/tajssei

Copyright: Original content from this work may be used under the terms of the creative commons attributes 4.0 licence.

\section{ABSTRACT}

This article describes the relationship between nationality and universality in ethnocultural group, the peculiarities of national culture. Moreover, it also studies ethnocultural group as the core of the national culture, the form of exaggerating the beauty, and splendor of the protagonist in the grotesque style, the harmony with the morality and beauty in Uzbek ethnocultural group and the factors that influencing the formation of national and universal characteristics in ethnocultural group.

\section{KEYWORDS}

Ethnocultural group, uzbek, nation, ethic group, nationality, universality, materialistic and spiritual aesthetic, value, folklore.

\section{INTRODUCTION}

National culture and ethnocultural group are not exactly phenomena, national culture is broader than ethnocultural group. Ethnoculture took a vital role in the process of social and historical-cultural paradigm development of the people (ethnos), as a set of spiritual materials richly formed in the process of long socio-historical development.
Ethnoculture is the core of national culture as the sum of material and spiritual wealth created by ethnoses. Its main functional feature is to preserve the material and spiritual wealth created by ethnic groups, to pass it on to future generations, to serve the understanding of national identity, to install a 
sense of national pride, patriotism and nationalism in young people's mind.

\section{METHODOLOGY}

Since ethnoculture is a core part of national culture, it is true that we can't add "Chinese wall" between ethnoculture and national culture, they are always in dialectical unity and connection. However, it is not difficult to find ethnocultural features that aren't stable, and react quickly to external influences, and change.

The most important aesthetic value in Uzbek ethnoculture is that beauty is seen in harmony with morality. It is beauty, nobility and humanity that are expressed in Uzbek folk art at the level of unique aesthetic values. This can be seen in almost every nation's folklore, in folk songs and melodies, in folk proverbs and books. Let's have a look at a famous Uzbek epic "Alpomish". K. Yuldashev, a scholar who has approached to the epic "Alpomish" in terms of national moral and national-aesthetic values, writes: "To understand the nation, you need to know its spirit. The epic "Alpomish" is an incomparable artistic monument in terms of expressing the spiritual, moral and aesthetic world of the Uzbek people. Because in the play the Uzbek way of thinking, the way of exposure, aesthetic perception, the decisionmaking attitude are expressed very sensitively ... In our opinion, the center of the epic is ignorance, the effect of ignorance on people's fate. The "story" itself is large-scale, and influential. In fact, Alpomish was not created, but the result of word of mouth or it was sung. Because the feelings, emotions and experiences of the heroes of the epic have always been in the veins and blood of the great Turks. Those spiritual deeds, morals, and events were experienced by the Turkish people. It was sung. It was necessary to sing the fate of Alpomish. It was impossible not to sing about it" [1. 28]. But it was not spending time, singing for fun, but singing about beautiful moral and aesthetic values that are in the hearts and lives of the people.

The aesthetic aspects of Uzbek ethnoculture are reflected in the glorification of patriotism, nobility and courage as aesthetic ideals. No matter what folk tales, the protagonists are portrayed as a person with a beautiful image, noble qualities, courage and bravery. In the artistic and aesthetic image, these noble qualities become the social ideal that generations envy and follow. Folklore exaggerates the beauty of the protagonist in a grotesque style, bringing the attitude to the protagonist to the forefront of all images. In romantic epics, fairy tales and songs, the main artistic method is to portray the protagonists as beautiful, rich, and cheerful, and to portray the young lovers as brave, courageous, and at the same time as a Muslim holy man (dervish). These beautiful, cheerful and charming faces of the protagonists give the reader an ideal image. This image embodies the dreams, ideals and glory of the people.

Oral and folklore books are full of contradictions, tragedies and dramas. Lovers reach out to each other after long and colorful trials.

\section{RESULTS}

The heroes of the Uzbek people are supporters of mad love, loyal companion, loyal friend, lover, gentle taste and gentleness. While they give up their interests and peace, they do not give up on their loved ones, friends and relatives. These beautiful, noble human feelings in them become unique artistic and aesthetic images.

It should also be noted that when you appreciate the beauty, splendor and figure of the national heroes, you will not fall in love with this image. Beauty is the beginning and the embodiment of the noble qualities and glorious goals of the hero. There is no hero, like larsiss in ancient Greek mythology, is 
fascinated by his own beauty and is inseparable from his country and his worries. People's heroes create a socio-aesthetic ideal through their noble deeds, love for their homeland and family, and sincere service to them. "Beauty is not beauty, a person who has love is beauty", says an Uzbek proverb. That is, it is not the beautiful appearance that matters, but the delicate, unique feeling in the human heart. Outward beauty is a gift of nature, but it becomes human when it is combined with inner, spiritual feeling.

National characteristics can be found in almost all forms and manifestations of folk culture. For example, Navruz celebrates the hard work of our people, conservation of the land, the formation of labor skills in young people, enjoying the beauty of Mother Nature, preserving nature, celebrating the results of labor, celebrating the Melon holiday. On one of the national holidays, Navruz, Uzbeks put a variety of dried fruit juices, painted eggs and other delicacies on the table. Candles were lit to cheer the spirits of the ghosts. At the Navruz table, of course, a large bowl was filled with water and green leaves were placed on it. This custom meant that the new year would be full of water and crops. In general, at the heart of all the traditions of "Navruz" lies the only noble intention of the people - the hope that the New Year will be a year of prosperity and abundance. The great scholar of the East, Umar Khayyam, in his book Navruznama, which is dedicated to this holiday, said: inevitably" [2.36].

Universality is also reflected in the ideas, plots and works that support the friendly relations and integration between peoples, nations and states. The fact that the epic "Alpomish" is spread in almost all Turkic peoples, the fairy tale "Three brothers are heroes" in the oral tradition of almost all peoples, the plots of friendship of different nationalities, romantic adventures are international portraits, folk culture is constantly integrated indicates that it is affected. Isolationism was not a cultural phenomenon, and international relations and dialogue brought universal motives, themes, and aesthetic ideals into ethnocultural processes [3.16].

The universality of Uzbek culture and its aesthetic values are the result of the cultural ties of the Uzbek people with other fraternal nations, especially the people of Central Asia. Therefore, not only in some plots, artistic and aesthetic images and ideals there is closeness and authenticity, but also in the whole works, folk books, folk songs, melodies and games, the art of pattern. For example, the epic "Oshiq Gharib and Shokhsanam" is present in the Uzbek folklore, in the Turkmen folklore, in the Khorezmian Lezgi, both in our country and in Azerbaijan. We see that blue, light blue and green colors in the patterns are more common among the Uzbek, Tajik and Kyrgyz peoples. Red and octagonal patterns on Turkmen carpets are widely used in Azeri and Turkish. Thus, many artistic and aesthetic images and plots of Uzbek ethnoculture have been formed under the influence of long socio-historical development and cultural integration. Therefore, the ethnocultural processes in Central Asia have been a product of integration. That is, first, such cultural integration was a direct effect of historical development; secondly, it was the basis of the Central Asian civilization with its own history and dynamics; and third, the spiritual riches that are common to all the peoples of the region [4. 13]. That is why the people of our region understand each other's cultures, traditions, artistic and aesthetic thoughts and ideas without any comments or translators, and can easily distinguish them from other cultures in other regions. The richness and playfulness of the melodies, the elegance and agility of the dances, the richness of the patterns and the choice of colors, the epic and polystyrene in the oral art, the openness and syncretism in the folk festivals and performances are the artistic and aesthetic features of our culture. 
Factors such as the natural and geographical environment in which the ethnos lived, the specificity of the way of life, social relations, especially the types of work, also influenced the formation of national and universal characteristics. These factors have affected the world, the environment and the socio-cultural life of the people. Therefore, although they live in different regions, there are many similarities in the culture of people with the similar natural and geographical environment [5. 38-41]. But the main focus should not be on the factors that lead to the isolation of ethnocultures. No matter how important it is to study the philosophical aspects of national identity, it is important to identify the universal features in them, to find the means to ensure the integration of ethnocultures, artistic and aesthetic values.

Nationality and universality in Uzbek ethnoculture are reflected in the harmony of aesthetic and moral values. In Uzbek folk art, moral values are described as beautiful, noble qualities. In this way, they rise to the level of not only moral but also aesthetic values.

\section{CONCLUSION}

While ethnoculture is stable and sometimes conservative, it is full of future-oriented artifacts, values, ideas, and experiences. This immanent feature of ethnoculture gives national culture its uniqueness. Hence, the nationality and stability of a culture is due to the richness and strength of its ethnocultural core.

\section{REFERENCES}

1. Yuldashev K. Interpretations of "Alpomish". - Tashkent: Manaviyat, 2002. $28 \mathrm{p}$.

2. Qoraboev U.H. Uzbek national holidays. Tashkent: Sharq, 2002. - 36 p.

3. Mukhitdinova D.M. National aesthetic culture: identity and development problems (social and philosophical aspect).
Author's abstract. diss ... cand. Philos. sciences. - Tashkent: 2005. -16 p.

4. Khamraev F.Sh. Socio-philosophical analysis of the integration processes of the cultures of the peoples of independent sovereigns in Central Asia. Abstract dissertation. cand. philos. sciences. Tashkent: 2002. - 13 p.

5. Klakhon K. Mirror for man. Introduction to Anthropology. - SPb.: Eurasia, 1998. - P. 38-41. 